\title{
Combustion Synthesis of TiC-Fe Composites under the Action of an Electric Field
}

\author{
Keqin FENG, ${ }^{1)}$ Chenguang BAI, ${ }^{2)}$ Yi YANG, ${ }^{1)}$ Wenjuan WANG ${ }^{1)}$ and Fang $\mathrm{JI}^{11}$ \\ 1) School of Manufacturing Science and Engineering, Sichuan University, Chengdu, Sichuan 610065, P.R.China. \\ E-mail: kq_feng@sina.com, yang_10@tom.com, wangwenjuan249@126.com, JiFang_24680@163.com \\ 2) College of Materials Science and Engineering, Chongqing University, Chongqing 400044, P.R.China. \\ E-mail: bguang@cqu.edu.cn
}

(Received on December 28, 2006; accepted on March 7, 2007)

\begin{abstract}
Using thermal simulation equipment, the combustion synthesis process of the compact of $55 w t \%(T i+C)-45 w t \% F e$ was studied. The results show that the ignition temperature of Fe-Ti-C system can be decreased greatly under the action of electric field and great thermal density. Before heating up to $350^{\circ} \mathrm{C}$, although there is no reaction takes place in the system, the microstructure of the system changes with the temperature; During heating from $350-470^{\circ} \mathrm{C}$, a thermal explosion phenomenon appears. Especially in the earlier stage of the combustion reaction, the dominant reaction is the one synthesized $\mathrm{TiC}$; As the temperature up to $670^{\circ} \mathrm{C}$ continuously, $\mathrm{Ti}_{(\mathrm{s})}+\mathrm{C}_{(\mathrm{s})}=\mathrm{TiC}_{(\mathrm{s})}$ reaction takes place accompanying with $2 \mathrm{Fe}_{(\mathrm{s})}+\mathrm{Ti}_{(\mathrm{s})}=\mathrm{Fe}_{2} \mathrm{Ti}_{(\mathrm{s})}$, and the conversion degrees of these reactions are increasing with the temperature increasing gradually. However, a part of $\mathrm{Fe}_{2} \mathrm{Ti}$ will be decompounded with the temperature increasing further, as a result, $\mathrm{Ti}_{(\mathrm{s})}+\mathrm{C}_{(\mathrm{s})}=\mathrm{TiC}_{(\mathrm{s})}$ will go on because of the addition $\mathrm{Ti}$. Consequently, the synthesized product consist of $\mathrm{Fe}, \mathrm{TiC}$ and a little of $\mathrm{Fe}_{2} \mathrm{Ti}$, and ultrafine $\mathrm{TiC}$ particles distribute in the Fe matrix uniformly.
\end{abstract}

KEY WORDS: combustion synthesis; electric field; Fe-Ti-C system.

\section{Introduction}

As a materials synthesis technology development rapidly in last decade or so, combustion synthesis (CS) has been successfully applying in the synthesis of high temperature refractory materials such as ceramic, metal-ceramic composition and intermetallics. ${ }^{1-3)}$ Those fields such as electric, magnetic and micro-gravity activated CS can be put into effective use in the system which is difficult to occur or react incompletely under normal condition, so it has been one of the important research aspects. ${ }^{4-6)}$

The research group led by Z. A. Munir is a typical representation of electric field activated CS, they have synthesized many kinds of materials by this method and carried out a quality of research. ${ }^{5,6)}$ However, the electric field is put into use only when the system is ignited by outside ignited equipment in their research, in other word, electric field play the roles just in maintaining and controlling the process of combustion synthesis. Different from their method, the outside ignited equipment isn't needed in our research, and an electric field play the roles not only in maintaining and controlling the process of combustion, but also in promoting diffusion process among the reactant atoms at low temperature in order to reduce the starting temperature of reaction. ${ }^{7,8)}$

TiC-Fe composites which can be used as cutting, machining and wear resistance materials draw much attention because of their extremely high hardness and toughness attributes. Although there are a few reports about the com- bustion synthesis of $\mathrm{TiC}-\mathrm{Fe}$ composites from $\mathrm{Ti}, \mathrm{C}$ and $\mathrm{Fe}$ powders, all of them are based on conventional combustion synthesis. ${ }^{9-11)}$ The adiabatic temperature $\left(T_{\mathrm{ad}}\right)$ of Fe-Ti-C system decreases with the increasing of Fe content, accompanying $\mathrm{Fe}-\mathrm{Ti}-\mathrm{C}$ system changes from strong exothermic to weak exothermic system, and the conventional CS can't be realized when Fe content is more than $60 \mathrm{wt} \%{ }^{9,10)}$ Moreover, the conventional CS need high ignition temperature, and the lowest ignition temperature of $\mathrm{Fe}-\mathrm{Ti}-\mathrm{C}$ system is $1060^{\circ} \mathrm{C}$ in all reported literatures. ${ }^{11)}$ As a result, TiC particles in produce are liable to grow up, which make against the quality of this composite.

According to the previous research results, the ignition temperature of system can be decreased greatly under the action of electric field and great thermal density. ${ }^{7,8)}$ In order to overcome the shortcoming of conventional $\mathrm{CS}$, electric field activated CS is a effective method of preparing high quality composites. At present, there is none of report about electric field activated the system of $\mathrm{Fe}-\mathrm{Ti}-\mathrm{C}$ combustion synthesis except for our research group. In this paper, the process of combustion synthesis of $55 \mathrm{wt} \%(\mathrm{Ti}+\mathrm{C})-$ $45 \mathrm{wt} \% \mathrm{Fe}$ system with $T_{\mathrm{ad}}=2000 \mathrm{~K}^{3)}$ under the action of an electric field was studied.

\section{Experimental}

Powders of titanium, graphite and iron, all of them with a $99 \%$ purity, and the typical average size of $\sim 60 \mu \mathrm{m}$, were mixed thoroughly with $55 \mathrm{wt} \%(\mathrm{Ti}+\mathrm{C})-45 \mathrm{wt} \% \mathrm{Fe} \quad(\mathrm{Ti} / \mathrm{C}$ 


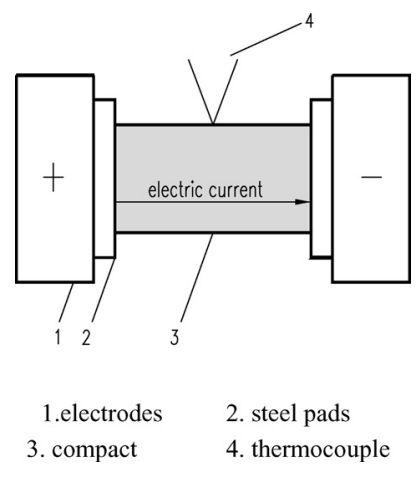

Fig. 1. Schematic representation of Gleeble equipment

molar ratio of $1: 1)$ using a ball mill for $6 \mathrm{~h}$. Then the mixed powders were compressed in a steel-mould to form a green compact with diameter $12.8 \mathrm{~mm}$, height $13.6 \mathrm{~mm}$ and relative density of $73 \%$.

Figure 1 shows the schematic of Gleeble thermal simulation equipment used in the experiments. It controls heating route and collects temperature data of a sample automatically by a computer system. Moreover, the character of this electric field is low voltage and large current.

In the experiment, no sooner had a series of same green compact been heated individually up to $250^{\circ} \mathrm{C}, 350^{\circ} \mathrm{C}$, $470^{\circ} \mathrm{C}, 670^{\circ} \mathrm{C}$ and $800^{\circ} \mathrm{C}$ at preset heating rate of $600^{\circ} \mathrm{C} / \mathrm{s}$ in vacuum $\left(<10^{-4} \mathrm{~Pa}\right)$ by the large electric current $(\sim 16500 \mathrm{~A})$ passing through them than the power was turn off. Meanwhile, the actual temperature data of the compact during the experiment were recorded at a frequency of $20 \mathrm{~Hz}$. Finally, the components of synthesized products were identified by XRD, and microstructures were acquired by a metalloscope and SEM.

It should be mentioned that the selection of heating temperature is according to the results of the thermal analysis and high-temperature XRD of this system. Moreover, the fact of that the temperature distribution within the sample during the whole heating process is rather uniform was proved by previous test, for example, the maximum difference in temperature which is between the surface and centre of sample is just only $3-5^{\circ} \mathrm{C}$, so in this experiment only the surface temperature was test conveniently.

\section{Results and Discussion}

\subsection{Products Characteristic}

The XRD of the products of the samples under different heating temperatures are shown in Fig. 2. From Fig. 2 it can been seen that: the final component of samples heated up to $250^{\circ} \mathrm{C}, 350^{\circ} \mathrm{C}$ both consist of $\mathrm{Fe}$, Ti and $\mathrm{C}$, which indicate that there is no reaction occur in the system before heating up to $350^{\circ} \mathrm{C}$; the products of the sample heated up to $470^{\circ} \mathrm{C}$ consist of new phase- $\mathrm{TiC}$ besides $\mathrm{Fe}$, $\mathrm{Ti}$ and $\mathrm{C}$, which demonstrates that there is an uncompleted reaction $\mathrm{Ti}_{(\mathrm{s})}+\mathrm{C}_{(\mathrm{s})}=\mathrm{TiC}_{(\mathrm{s})}$ in the system before heating up to $470^{\circ} \mathrm{C}$; the products of the sample heated up to $670^{\circ} \mathrm{C}$ consist of new phase- $\mathrm{Fe}_{2} \mathrm{Ti}$ besides $\mathrm{Fe}, \mathrm{C}, \mathrm{TiC}$ without $\mathrm{Ti}$, which indicates that $\mathrm{Ti}_{(\mathrm{s})}+\mathrm{C}_{(\mathrm{s})}=\mathrm{TiC}_{(\mathrm{s})}$ reaction takes place accompanying with $2 \mathrm{Fe}_{(\mathrm{s})}+\mathrm{Ti}_{(\mathrm{s})}=\mathrm{Fe}_{2} \mathrm{Ti}_{(\mathrm{s})}$ reaction, and reactant $\mathrm{Ti}$ is almost run out during this period; and the products of the sample heated up to $800^{\circ} \mathrm{C}$ consist of $\mathrm{Fe}, \mathrm{TiC}$ and a little of

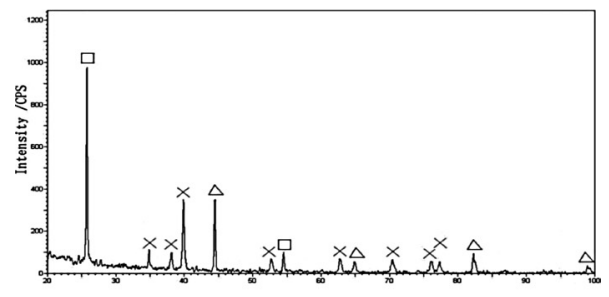

(a) $250{ }^{\circ} \mathrm{C}$

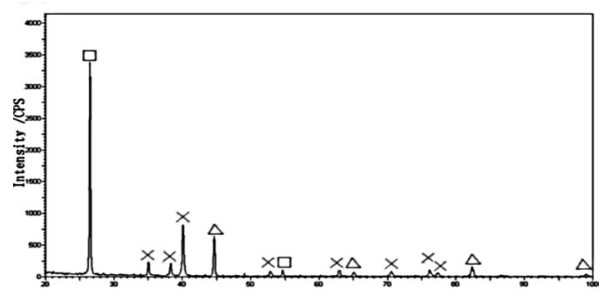

(b) $350{ }^{\circ} \mathrm{C}$

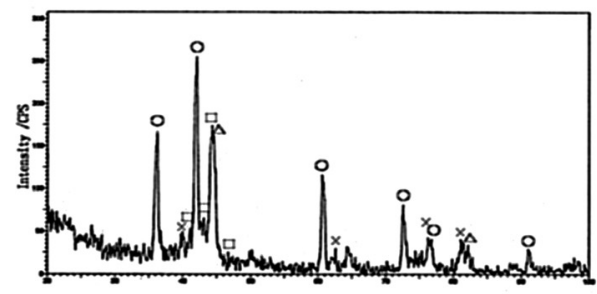

(c) $470{ }^{\circ} \mathrm{C}$

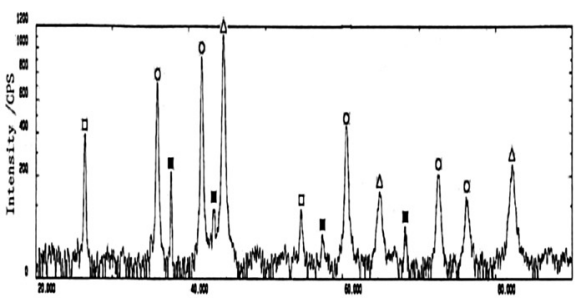

(d) $670{ }^{\circ} \mathrm{C}$

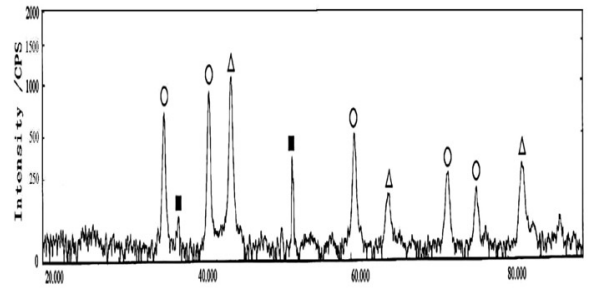

(e) $800^{\circ} \mathrm{C}$

$2 \theta /{ }^{\circ}$

$$
\triangle-\mathrm{Fe} \quad \times-\mathrm{Ti} \quad \square-\mathrm{C} \quad \mathrm{O}-\mathrm{TiC} \quad \boldsymbol{\square}-\mathrm{Fe}_{2} \mathrm{Ti}
$$

Fig. 2. X-ray diffraction patterns of synthesized products.

$\mathrm{Fe}_{2} \mathrm{Ti}$, which is similar to the conventional $\mathrm{CS},{ }^{9-11)}$ and it indicates that a part of $\mathrm{Fe}_{2} \mathrm{Ti}$ will be decompounded so as to change into $\mathrm{TiC}$.

As shown in Fig. 3, although there is no reaction occur in the system heated up to $250^{\circ} \mathrm{C}$ and $350^{\circ} \mathrm{C}$, the microstructure of system has been changed to some degree, it can be seen that the interface between reactant particles of the compact heated up to $350^{\circ} \mathrm{C}$ is clearer than that one heated up to $250^{\circ} \mathrm{C}$. And then, from Fig. 4 showed the SEM photos of samples heated up to $470^{\circ} \mathrm{C}, 670^{\circ} \mathrm{C}$ and $800^{\circ} \mathrm{C}$, it can be seen that there are a great deal of $300-800 \mathrm{~nm}$ grey spherical particles which were identified as TiC by EDS 


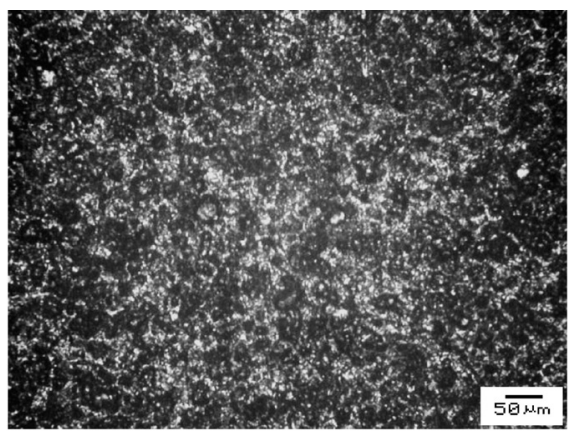

(a) $250^{\circ} \mathrm{C}$

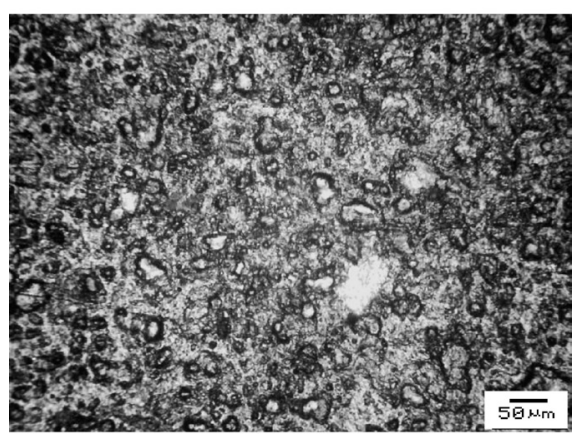

(b) $350^{\circ} \mathrm{C}$

Fig. 3. The metallographic photos of samples of heating temperature $250,350^{\circ} \mathrm{C}$.

distribute in Fe matrix uniformly. Moreover, the average size of $\mathrm{TiC}$ particles become larger associated with the heating temperature increasing.

\subsection{The Thermodynamical Analysis of Fe-Ti-C Sys- tem}

The reactions in $\mathrm{Fe}-\mathrm{Ti}-\mathrm{C}$ system almost occur in state of solid when $\mathrm{Fe}$ content is above $40 \mathrm{wt} \%{ }^{3,12}$ ) The phases which may be exist in this system under $800^{\circ} \mathrm{C}$ and the accompanying free energy changes that are calculated thermodynamically in this process condition are as follows ${ }^{13)}$ :

$$
\begin{aligned}
& \mathrm{Ti}_{(\mathrm{S})}+\mathrm{C}_{(\mathrm{S})}=\mathrm{TiC}_{(\mathrm{S})} \\
& \Delta G_{1}=-182875+10.0738 T \quad \mathrm{~J} / \mathrm{mol} \ldots \\
& 3 \mathrm{Fe}_{(\mathrm{S})}+\mathrm{C}_{(\mathrm{S})}=\mathrm{Fe}_{3} \mathrm{C}_{(\mathrm{S})} \\
& \Delta G_{2}=26668.4-24.7456 \mathrm{~J} \mathrm{~J} / \mathrm{mol} \ldots \\
& 2 \mathrm{Fe}_{(\mathrm{S})}+\mathrm{Ti}_{(\mathrm{S})}=\mathrm{Fe}_{2} \mathrm{Ti}_{(\mathrm{S})} \\
& \Delta G_{3}=-87860+89.00 T \quad \mathrm{~J} / \mathrm{mol} \ldots \ldots \ldots
\end{aligned}
$$

Where $\Delta G$ is free energy change.

Figure 5 describes the free energy changes of the above reactions. Based on these equations and Fig. 5, it can be seen that the $\Delta G$ values of Eq. (1) is negative except that of Eq. (2) is positive below $800^{\circ} \mathrm{C}$, and that of Eq. (3) is negative just below $714^{\circ} \mathrm{C}$ and larger than that of Eq. (1). As a result, it reveals thermodynamically that the chemical reaction of $\mathrm{Ti}_{(\mathrm{S})}+\mathrm{C}_{(\mathrm{S})}=\mathrm{TiC}_{(\mathrm{S})}$ can take place below $800^{\circ} \mathrm{C}$, and $\mathrm{TiC}$ is the most stable phase in the system. On the contrary, the chemical reaction of $3 \mathrm{Fe}_{(\mathrm{S})}+\mathrm{C}_{(\mathrm{S})}=\mathrm{Fe}_{3} \mathrm{C}_{(\mathrm{S})}$ can't take

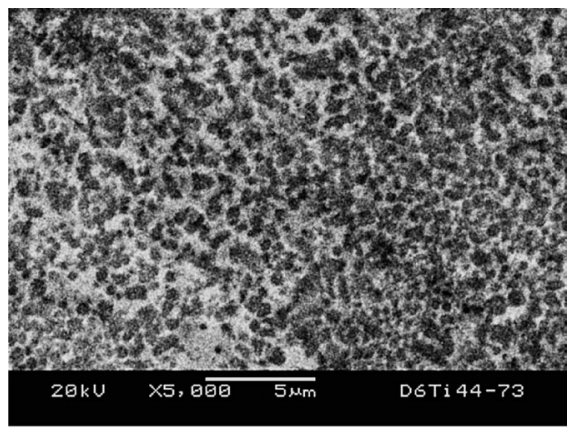

(a) $470^{\circ} \mathrm{C}$

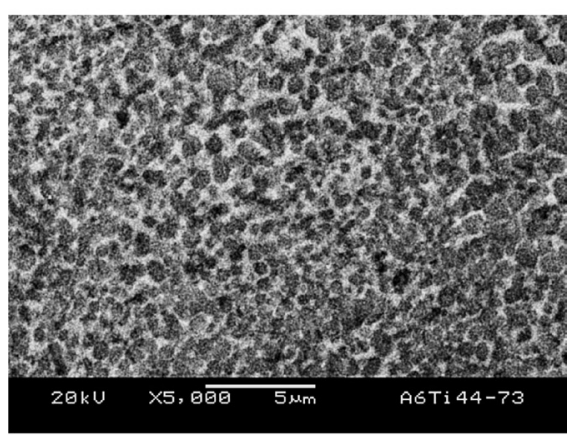

(b) $670^{\circ} \mathrm{C}$

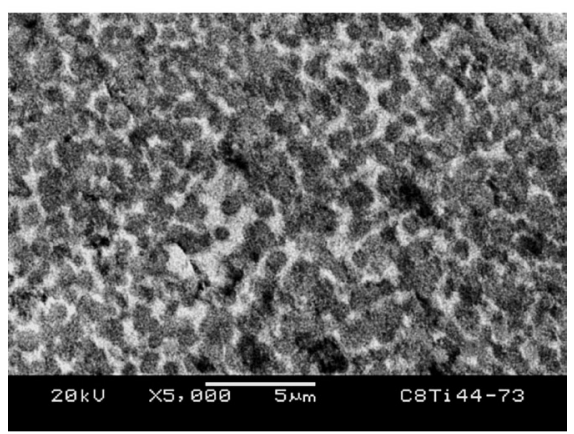

(c) $800^{\circ} \mathrm{C}$

Fig. 4. SEM photos of samples of heating temperature 470,670 , $800^{\circ} \mathrm{C}$.

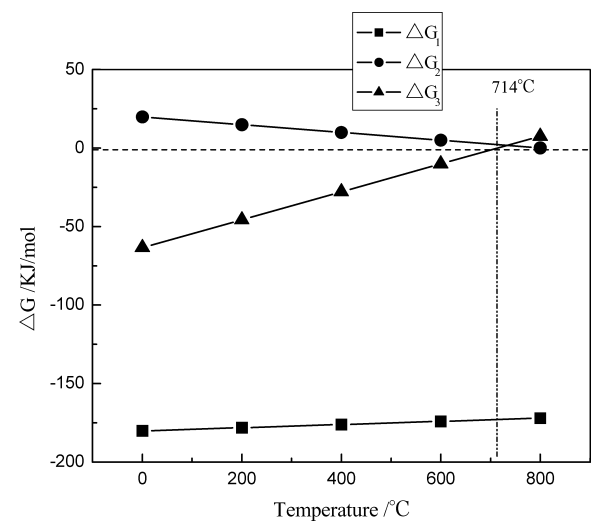

Fig. 5. The $\Delta G$ of equations as function of temperature in the system of $\mathrm{Fe}-\mathrm{Ti}-\mathrm{C}$.

place below $800^{\circ} \mathrm{C}$. However, the chemical reaction of $2 \mathrm{Fe}_{(\mathrm{S})}+\mathrm{Ti}_{(\mathrm{S})}=\mathrm{Fe}_{2} \mathrm{Ti}_{(\mathrm{S})}$ can take place below $714^{\circ} \mathrm{C}$, but $\mathrm{Fe}_{2} \mathrm{Ti}$ will be decompounded above $714^{\circ} \mathrm{C}$. It is said that $\mathrm{Fe}_{2} \mathrm{Ti}$ is the non-equilibrium transition phase of the nonequilibrium process-CS. 


\subsection{The Process of Combustion Synthesis of Fe-Ti-C System}

In the condition of an electric field, the large electric current acquired by presetting heat rate up to $600^{\circ} \mathrm{C} / \mathrm{s}$ can provide larger thermal density for $\mathrm{Fe}-\mathrm{Ti}-\mathrm{C}$ system. And then the common roles of electric and thermal field can provide the great contribution for the solid diffusion among reactant atoms at low temperature. For example, in Fig. 4(c), the EDS results which show that grey particle consist of 7.12 at $\% \mathrm{Fe}, 74.24 \mathrm{at} \% \mathrm{Ti}$ and $18.64 \mathrm{at} \% \mathrm{C}$ and white area consist of 84.39 at $\% \mathrm{Fe}, 3.79$ at $\% \mathrm{Ti}$ and $11.82 \mathrm{at} \% \mathrm{C}$ demonstrate that not only $\mathrm{C}$ and $\mathrm{Fe}$ diffuse into Ti, but $\mathrm{C}$ and $\mathrm{Ti}$ also diffuse into $\mathrm{Fe}$ in the process of combustion synthesis of $\mathrm{Fe}-\mathrm{Ti}-\mathrm{C}$ system. In the same temperature, the rate of interstitial diffusion is higher than that of substitutional diffusion. ${ }^{14)}$ Diffusion of $\mathrm{C}$ into $\mathrm{Ti}$ and $\mathrm{Fe}$ occur by the interstitial diffusion, but the diffusion of Ti into $\mathrm{Fe}$ or Fe into Ti occurs by substitutional diffusion. So it can be suggested that the diffusion rate of $\mathrm{C}$ into $\mathrm{Ti}$ and $\mathrm{Fe}$ is higher than that of $\mathrm{Ti}$ into $\mathrm{Fe}$ or $\mathrm{Fe}$ into $\mathrm{Ti}$, and the process of $\mathrm{Ti}$ into Fe or Fe into Ti may control the combustion synthesis process.

First, during the period of heating up to $350^{\circ} \mathrm{C}$, although both $\mathrm{Ti}_{(\mathrm{S})}+\mathrm{C}_{(\mathrm{S})}=\mathrm{TiC}_{(\mathrm{S})}$ and $2 \mathrm{Fe}_{(\mathrm{s})}+\mathrm{Ti}_{(\mathrm{s})}=\mathrm{Fe}_{2} \mathrm{Ti}_{(\mathrm{s})}$ reactions can occure according to the above thermodynamical analysis, there is no reaction takes place in the system because of deficient energy in so low temperature. However, both the solid diffusion of $\mathrm{C}, \mathrm{Fe}$ into $\mathrm{Ti}$ and $\mathrm{C}, \mathrm{Ti}$ into $\mathrm{Fe}$ are strengthened by the common effect of electric field and large thermal density, and the transport properties such as electric conductivity, thermal conductivity change with the temperature. As a result, the microstructure of system changes with the increasing of the temperature. Second, with the heating temperature ranges from $350-470^{\circ} \mathrm{C}$, the energy provided by the electric field for the system is rising gradually. When it is high enough to be ignited, a combustion phenomenon appears instantly throughout the entire sample which is named thermal explosion at the ignition temperature (the ignition temperature of this system is $394^{\circ} \mathrm{C}$, as reported in Ref. 7)). In the earlier stage of the combustion reaction, the dominant reaction is the one synthesized TiC because $\mathrm{Ti}_{(\mathrm{s})}+\mathrm{C}_{(\mathrm{s})}=\mathrm{TiC}_{(\mathrm{s})}$ reaction takes place more easily than $2 \mathrm{Fe}_{(\mathrm{s})}+\mathrm{Ti}_{(\mathrm{s})}=\mathrm{Fe}_{2} \mathrm{Ti}_{(\mathrm{s})}$ reaction. Third, as the temperature increases continuously from $470-670^{\circ} \mathrm{C}$, $\mathrm{Ti}_{(\mathrm{s})}+\mathrm{C}_{(\mathrm{s})}=\mathrm{TiC}_{(\mathrm{s})}$ reaction takes place accompanying with $2 \mathrm{Fe}_{(\mathrm{s})}+\mathrm{Ti}_{(\mathrm{s})}=\mathrm{Fe}_{2} \mathrm{Ti}_{(\mathrm{s})}$ reaction, and the degrees of conversion for these reactions are increasing gradually. Finally, when the temperature increases further, a part of $\mathrm{Fe}_{2} \mathrm{Ti}$ will be decompounded to $\mathrm{Fe}$ and $\mathrm{Ti}$, and then the addition $\mathrm{Ti}$ can react with the residual $\mathrm{C}$ until the temperature rises to the preset highest temperature $800^{\circ} \mathrm{C}$. Consequently, the syn- thesized products consist of $\mathrm{Fe}$, $\mathrm{TiC}$ and a little of $\mathrm{Fe}_{2} \mathrm{Ti}$ which is the transition phase of non-equilibrium process.

\section{Conclusions}

The ignited temperature of $\mathrm{Fe}-\mathrm{Ti}-\mathrm{C}$ system can be reduced greatly by the common roles of electric field and large thermal density.

The process of the electric field induced combustion synthesis can be described as follow: Before heating up to $350^{\circ} \mathrm{C}$, the solid diffusion among reactant atoms is strengthened gradually by the common effect of electric field and large thermal density with the temperature increasing. Although there is no reaction takes place in the system, the microstructure of system changes with the temperature; During heating from $350-470^{\circ} \mathrm{C}$, a thermal explosion phenomenon appears. Especially in the earlier stage of the combustion reaction, the dominant reaction is the one synthesized TiC; As the temperature up to $670^{\circ} \mathrm{C}$ continuously, $\mathrm{Ti}_{(\mathrm{s})}+\mathrm{C}_{(\mathrm{s})}=\mathrm{TiC}_{(\mathrm{s})}$ takes place accompanying with $2 \mathrm{Fe}_{(\mathrm{s})}+\mathrm{Ti}_{(\mathrm{s})}=\mathrm{Fe}_{2} \mathrm{Ti}_{(\mathrm{s})}$, and the conversion degrees of these reactions are increasing gradually. However, a part of $\mathrm{Fe}_{2} \mathrm{Ti}$ will be decompounded with the temperature increasing further, and $\mathrm{Ti}_{(\mathrm{s})}+\mathrm{C}_{(\mathrm{s})}=\mathrm{TiC}_{(\mathrm{s})}$ will go on because of the addition Ti. Consequently, the synthesized product consist of $\mathrm{Fe}, \mathrm{TiC}$ and a little of $\mathrm{Fe}_{2} \mathrm{Ti}$, and ultrafine $\mathrm{TiC}$ particles distribute in the Fe matrix uniformly.

\section{Acknowledgement}

This work were supported by the National Nature Science Foundation of China (No. 50404014) and China Postdoctoral Science Foundation (No. 20060390177).

\section{REFERENCES}

1) J. Subrahmanyam and M. Vijayakumar: J. Mater., 27 (1992), 6249

2) C. Raghunath and M. S. Bhat: Scr. Metall. Mater, 32 (1995), 577.

3) Z. Zhengguang: Technology and Application of Self-Propagation High-Temperature Synthesis of TiC/Fe Composites, Metallurgical Industry Press, Beijing, (2002), 69.

4) A. G. Merzhanov: Adv. Space Res., 29 (2002), 487.

5) R. Orru, A. Cincotti and Z. A. Munir: Chem. Eng. Sci., 56 (2001), 683.

6) Z. A. Munir: Mater. Sci. Eng. A, A287 (2000), 125.

7) K. Q. Feng and Y. Yang: Rare Met. Mater. Eng., 34 (2005), 479.

8) Y. Yang and K. Q. Feng: Powder Metall., 49 (2006), 135.

9) Q. C. Fan and H. F. Chai: J. Mater. Process. Technol., 96 (1999), 102.

10) A. Saidi and A. Chrysanthou: J. Mater. Sci., 29 (1994), 4993.

11) M. J. Capaldi and A. Saidi: ISIJ Int., 37 (1997), 188.

12) Q. C. Fan and H. F. Chai: J. Mater. Sci., 32 (1997), 4319.

13) Y. J. Liang and Y. C. Che: Hand Book for Thermodynamics Data of Inorganic Matter, Northeastern University, Shengyang, (1993), 136.

14) J. D. Verhoeve: Fundamentals of Physical Metallurgy, Wiley, New York, NY, (1975), 143. 